$\left.\begin{array}{l}\text { Sournals } \\ \text { ONTERNATIONAL JOURNAL OF } \\ \text { ORGANIZATIONAL LEADERSHIP }\end{array}\right) \begin{gathered}\text { INDUSTRIAL } \\ \text { MANAGEMENT } \\ \text { INSTITUTE }\end{gathered}$

\title{
An investigation of the factors effective in human resources branding and its effect on the reputation and brand of insurance industry
}

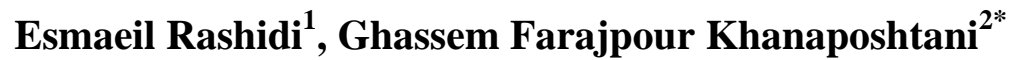 \\ ${ }^{1}$ M.Sc. Student, Department of Industrial Engineering, Parand Branch, Islamic Azad University, Parand, Iran \\ ${ }^{2}$ Assistant Professor, Department of Industrial Engineering, Parand Branch, Islamic Azad University, Parand, \\ Iran
}

\begin{tabular}{|c|c|}
\hline & ABSTRACT \\
\hline \multicolumn{2}{|l|}{ Keywords: } \\
\hline $\begin{array}{l}\text { Brand, Human Resources } \\
\text { Branding, Human } \\
\text { Resources Processes, } \\
\text { Commitment, Satisfaction, } \\
\text { Competency }\end{array}$ & $\begin{array}{l}\text { Internal branding is a novel strategy focuses on brand equity to ensure that the staff aim at } \\
\text { improving the organizational reputation. Since the staffs are able to considerably effect the } \\
\text { customer's purchase behavior, they have a key role in establishing the reputation. In this } \\
\text { regard, human resource branding can improve the competitive aspects of organizations. } \\
\text { Inspiring of this fact, the current research concentrates on theinsurance industry and }\end{array}$ \\
\hline $\begin{array}{l}\text { Received } \\
14 \text { September2016 }\end{array}$ & $\begin{array}{l}\text { addresses to identifying the important factors in human resource branding and its effects on } \\
\text { reputation/brand in the mentioned area. For this aim, data are gathered from different }\end{array}$ \\
\hline $\begin{array}{l}\text { Received in revised form } \\
31 \text { March } 2017\end{array}$ & $\begin{array}{l}\text { Insurance branches in Alborz province and model confirmation is conducted based on the } \\
\text { structural equations modeling and confirmatory factor analysis. After model confirmation, }\end{array}$ \\
\hline $\begin{array}{l}\text { Accepted } \\
31 \text { March } 2017\end{array}$ & $\begin{array}{l}\text { the experiments affirm that the human resource process has adirect effect on the } \\
\text { competency, commitment and satisfactory. Subsequently, it is admissible that the three } \\
\text { mentioned factors have adirect effect on reputation. }\end{array}$ \\
\hline
\end{tabular}

Correspondence:

ghfarajpour44@gmail.com

(C)AIMI Journals

Nowadays, many organizations lead their large investments to branding to own a strong and valuable brand, so that the concepts and values of this brand will be transferred to customers through communications and advertisements and it will create a more qualified identity in their minds. In fact, these organizations believe that the customers' minds play a key role in their decision-making on purchasing. On the other hand, each employee in the organization as the production or service-provider element is the link between the organization and customers and 
has agreater effect on customers than advertisements (Hosseini, Mousavi, \& ZiaeeBideh, 2013).

Brand development based on human resources (employer brand) was proposed for two decades in marketing and human resource management literature. Although there are various definitions for this concept, it is usually considered as an image of the characteristics of an organization (as an employer) in the mind of internal employees and applicants for that organization. According to employees and applicants, the positive brand of an organization makes the organization as an appropriate environment to work in. Leading organizations attempt to employ, train, keep, and use knowledgeable and skilled forces, so that their present and future competitive advantage will be guaranteed (Sheida, Hemmati, \& Fakhari, 2014).

Due to the increasing technology in the present competitive world, organizations spend a lot of money on the maximum productivity. The survival of organizations depends on agood performance to use the resources properly and achieve their objectives. Formulating a strategic plan for organizations is a necessary tool to maintain their survival and growth. Limited resources, increase in competition, and environmental conditions highlight this necessity. The present research searches for a method to identify and confirm the best procedures and improve the performance of brand reputation in services field. Inter-organizational branding with the aim of achieving brand equity based on employees is a modern strategy to ensure that employees act according to brand commitments. Since in service organizations employees are able to affect customers' purchasing decisions and play a key role in organization's success, reinforcing brand equity based on employees can create a sustainable competitive advantage for the organization (Sanavifard, 2014).

In this study, first, the concepts of brand, human resources branding, competency, commitment, and loyalty of employees are given.

\section{Brand}

Brand as a concept includes different definitions, however, in this research the most prominent definition is given. American Marketing Association defines abrand as a name, word, symbol, or a combination of these items which is aimed at introducing products or services of a salesperson or a group of salespeople to customers and differentiating their products from competitors' products. A particular brand adds some dimensions to a product or service so that they will be different from others. These differentiations may have logical, tangible, or intangible functions (Johansson, 2008).

Kotler (2003) provides a definition similar to American Marketing Association's; for example, thebrand is a name, term, sign, symbol, or a combination of these items which is aimed at introducing a product or service of a salesperson or a group of salespeople and differentiating them from the products of competitors.

In fact, these definitions are not comprehensive since they have faced criticism. The first criticism is about American Marketing Association's definition. In this definition, the product and its appearance are emphasized, while brands are used not only for consumption products but also for places, organizations, or people (Seddighi, 2015).

\section{Human Resources Branding}


Brand equity and human capital are two critical assets that support a firm's short-term stability and long-term success. While businesses have recognized the power of brand management for attracting and retaining external customers, companies are only beginning to realize the potential benefits of HR brand management for attracting, selecting, and retaining internal customers (i.e., employees). Human resources branding is culture changes management and culture building(Hosseini et al., 2013).

The main purpose of human resource branding is to induce the brand identity among the staffs which lead to having a unique viewpoint and goal for them. The unique viewpoint is the main beneficial interaction between the brand identity and inter-organization activities. After establishing the brand identity, the next layers will focus on constituting the commitment (loyalty), satisfactory and competency to advancement the next steps of branding(Omidikia, Moshabbaki, Khodadadhosseyni, \& Azizi, 2012).

According to executive experiences, in order to apply such changes, time and accuracy are of great importance. Since in forming new behavior, moving plans from previous behavior to new behavior are required, punishment and reward system must analyze all behavior and events within the organization and encourage theacceptable behavior. Since current values are institutionalized undesirably due to reinforcing previous behavior, new values must desirably change into behavior (Punjaisri \& Wilson, 2011).

Implementing branding plans reinforces the defined identity of a brand in an organization and creates anon-copyable competitive advantage. Preparing abrand book of the organization and implementing its defined elements in the external market of the organization are the initial point of a wavy movement which requires continuity by means of an internal force. Branding as a propulsive force guarantees the survival of a brand. Therefore, internal branding is essential in any branding plans (whether the company produces a product or offers a service) (Schlager, Bodderas, Maas, \& Cachelin, 2011).

The aim of branding is to achieve social architecture and a particular combination of organizational values that lead the employees to particular behavior and pattern. This cultural pattern can create defined values and behavior when new employees enter the organization and reproduce organizational values similar to a company. It is expected that inter-organizational brand plan creates a social pattern which is a form of sustainable competitive advantage and a combination of humans, values, and behavior that cannot be simulated by any other organizations (Wallace, Chernatony, \& Buil, 2013).

In brand human resources management, jobs are analyzed according to business processes. Organizational positions are arranged according to business process facilitation. The objectives of thebrand are connected to the employees' evaluation mechanism as well as punishment and reward system. The employment system is organized and the objectives of thebrand are considered as determining elements. Welfare plans are designed to support the nature of the brand. The communicational and mental problems of the organization are identified through periodic interviews by brand human resources consultant. Training courses are provided according to the defined values of the organization and employees develop their skills and knowledge within the organization (Zaman Fashami, 2013). 


\section{The Process of Human Resources Management in IDRO Model}

In this model, the attraction models as studying and selecting the talented forces to train at the global level, development as training and solving short-term problems and planning the training concepts, keeping in the concept, and institutionalizing professional behavior are proposed. Therefore, formulating procedures or suggesting suitable rules, evaluating to reform managerial methods, getting feedback from the operations, and infrastructures for improving the culture of human resources management in the organization are required. Figure 1 indicates this model (Mohammadi \& Varzeshkar, 2009).

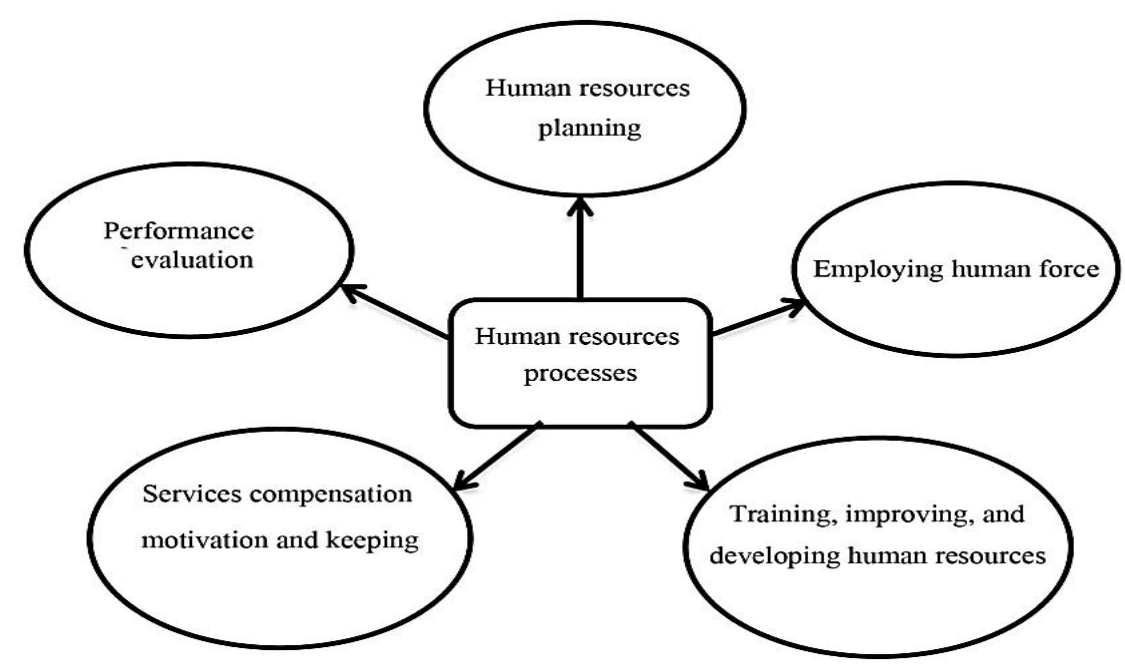

Figure 1. The pattern of human resources management system in IDRO (Industrial Development and Renovation Organization in Iran)

\section{Competency}

Since competency management determines the key knowledge needed by the person and organization to accomplish the objectives, it can play a leading role at individual and organizational level. Competency in human resources management is hidden in key concepts of human resources such as performance evaluation and selection, management, training, development, and reward management. Competency management is closely associated with the attempts of the organization to create employees' empowerment system to increase competitive advantage, innovation, and efficiency. Moreover, competency management is directly connected to the activities of the organization to reinforce the internal knowledge and apply knowledge management continually. Human capital is one of the most important assets of an organization. Effective use of human capital prepares the ground for the success of the organization and accomplishes its objectives. Different authors have presented different definitions for competency. Competency includes cognitive (such as knowledge and skill), emotional (such as attitudes and values), behavioral, and motivational characteristics, which enables the person to perform successfully in their position. Competency is a combination of motivation, characteristics, self-concept, attitudes, values, knowledge content, or cognitivebehavioral skills, which can differentiate between middle and premier employees. Competency fields indicate activities the person is competent at, while competencies based on the person include characteristics enabling the person to be competent in a particular field. In fact, 
competency fields are generally based on the occupation, while competencies are based on the person (Mohammadi Zanjirani, Eshtiaghian, \& Raznahan,2012).

\section{Commitment (Loyalty)}

Whiteoak and Mohamed (2016) considers organizational commitment as the tendency, attitude, or orientation that connects the person's identity to the organization and creates asimilarity between the organization and the member. In fact, commitment is the person's identity and dependency on the organization or their eagerness to work well.

\section{Job Satisfaction}

Job satisfaction theories are various and there are different ideas about job satisfaction theories. The initial studies on attitudes towards working started before World War I and actively followed in Britannia, Europe, and America. In recent centuries, socialists and psychologists have presented different ideas about working and job. Different aspects of working such as inequality in working, job satisfaction, job motivation, and anincrease in productivity of organizations have been considered by scientists of management, sociology, economy, and psychology (Spencer \& Byrne, 2016).

Job satisfaction includes a group of feelings and beliefs that people have about their current job. In fact, job satisfaction is one of the important factors in job success, which increases efficiency and personal satisfaction. Job satisfaction happens when the person likes their job requirements and conditions (Shafizadeh \& Kamrava, 2014).

Generally, job satisfaction happens when people are satisfied with their job and enjoy it, thus, they are attached to it. In fact, job satisfaction is a pleasant, emotional, and positive feeling derived from job evaluation.

Alipour and Farid (2013) consider job satisfaction as an internal factor and emotional compatibility with the occupation. If people enjoy their job, they will be satisfied with it and if they are not satisfied with their job, they will not enjoy it and will definitely change it.

Creating job satisfaction in employees will not happen fast, however, it will be destroyed very fast. For example, sometimes, job satisfaction is at its high level, but suddenly manager's wrong behavior destroys everything. According to the definitions of job satisfaction, this concept shows positive feelings and attitudes towards a particular job. When we say that people show high levels of job satisfaction, it means that they love their job, they place a high value on

it, they have a positive attitude towards it, and they feel pleasant about it (Ahmad \& Daud, 2016).

\section{Background of the Study}

There can be found many types of research in the literature focused on brand equity area. In this regard, for example, Gull and Mubeen Ashraf (2012) conducted a research to investigate the relation of inter-organizational branding and staff competency in information technology services. The results showed that inter-organization branding and competency are directly correlated i.e. branding can enhance the competency. Four main human resource management methods including training, orientation, meetings, and brain storming are considered to affirm the correlation in different parts of the organization. 
Punjaisri, Wilson, and Evanschitzky (2014) believe that human resource branding effects on the staffs' behavior in brand competency. Brand competency is ones that the organization has established among the customers via marketing and advertisement in which the organizational brand is reputed by this way. The researchers affirm that training, brain storming, and staffs meeting are key factors in improving the brand competency.

Kimpakorn and Tocquer (2010) describes that one of the main factors in establishing the service brand equity is experiencing the services by customers; where staffs have animportant role in this area. They affirm that staffs' competency has aneffect on the brand equity.

Different from aforementioned researches, other related works are also available. Table 1 illustrates some similar studies in the current area.

Table 1

The Literature Review in Human Resource Branding Area

\begin{tabular}{|c|c|c|}
\hline $\begin{array}{l}\text { Name of the } \\
\text { Researcher and Year }\end{array}$ & Title of the Research & A Summary of the Results \\
\hline $\begin{array}{l}\text { Eivazzadeh\&Moinan } \\
\text { (2011) }\end{array}$ & $\begin{array}{l}\text { The effect of human resources } \\
\text { management on improving the } \\
\text { efficiency of staff in Islamic Azad } \\
\text { University, East of Tehran Branch }\end{array}$ & $\begin{array}{l}\text { The main aim of this study is to evaluate the roles of organizational } \\
\text { management includes planning, attraction, employment, employee benefits } \\
\text { design and performance appraisal in Islamic Azad University, East Tehran } \\
\text { Branch. The statistical population consists of } 90 \text { persons which are } \\
\text { sampled randomly. The computed p-value equal to } 0.01 \text { shows that the } \\
\text { relation between the human resource management and productivity is } \\
\text { admissible. }\end{array}$ \\
\hline $\begin{array}{l}\text { Bagheri\&Tavallai } \\
(2010)\end{array}$ & $\begin{array}{l}\text { An investigation of the effect of } \\
\text { organizational commitment on the } \\
\text { performance of organizations }\end{array}$ & $\begin{array}{l}\text { Employees' organizational commitment can lead to satisfaction, } \\
\text { attachment, and dependence on the organization, more appropriate job } \\
\text { performance, employees' stay in the organization, active social behavior, } \\
\text { no absence from the work, altruism and helping the colleagues, low job } \\
\text { stress, financial success, and increase in efficiency of the organization. }\end{array}$ \\
\hline $\begin{array}{l}\text { Kafashpour\&Niakan } \\
\text { (2011) }\end{array}$ & $\begin{array}{l}\text { Recognizing the effective and } \\
\text { determining inter-organizational } \\
\text { factors to create a valuable brand }\end{array}$ & $\begin{array}{l}\text { The statistical papulation was administrative managers; where, the } \\
\text { analyses were conducted via questionnaires and one-tailed T-test. It is } \\
\text { approved that the internal environment has aneffect on thebrand. }\end{array}$ \\
\hline Hosseini et al. (2013) & $\begin{array}{l}\text { Presenting a model for employee-based } \\
\text { brand equity in business insurance } \\
\text { office of Yazd Province }\end{array}$ & $\begin{array}{l}\text { The main aim was to present a model to investigate brand equity form staff } \\
\text { viewpoint and also identify its effective factors in theinsurance industry. } \\
\text { The related data gathered using questionnaires among } 4 \text { insurance staffs in } \\
\text { Yazd province. Structural equations are used based on the partial least } \\
\text { square to test the hypotheses. The results affirm the relation between staff } \\
\text { feedback, brand inter-relation and brand equity. Another important finding } \\
\text { is presenting a staff-based model for measuring brand equity. }\end{array}$ \\
\hline $\begin{array}{l}\text { Ghorbanifard, } \\
\text { Hashemnia, \& } \\
\text { Mousavi (2014) }\end{array}$ & $\begin{array}{l}\text { The effect of organizational } \\
\text { atmosphere dimensions on brand } \\
\text { promise }\end{array}$ & $\begin{array}{l}\text { The statistical population is Bank Maskan staffs in Alborz province which } \\
\text { samples are selected randomly. Standard questionnaires are employed for } \\
\text { data gathering. In addition, spearman hypothesis test and multiple } \\
\text { regression are used for data analysis. Results show that organizational } \\
\text { competence, team-work, staffs' benefit, organizational } \\
\text { communication/structure, and brand competence can realize the brand } \\
\text { competence. }\end{array}$ \\
\hline $\begin{array}{l}\text { Baumgarth\& } \\
\text { Schmidt (2010) }\end{array}$ & $\begin{array}{l}\text { How strong is the business-to-business } \\
\text { brand in the workforce? An } \\
\text { empirically-tested model of internal } \\
\text { brand equity in a business-to-business } \\
\text { setting }\end{array}$ & $\begin{array}{l}\text { Inter-organizational brand equity, brand loyalty, inter-role behavior of the } \\
\text { brand, and intra-role behavior of the brand } \\
\text { Brand Commitment } \rightarrow \text { Equity based on Employees } \\
\text { Brand Knowledge } \rightarrow \text { Equity based on Employees } \\
\text { Inter-Organizational Equity } \rightarrow \text { Equity based on Customers }\end{array}$ \\
\hline $\begin{array}{l}\text { Kimpakorn\&Tocquer } \\
(2010)\end{array}$ & $\begin{array}{l}\text { Service brand equity and employee } \\
\text { brand commitment }\end{array}$ & Employees' Commitment to the Brand $\rightarrow$ Equity based on Customers \\
\hline $\begin{array}{l}\text { Burmann\&Zeplin } \\
\text { (2005) }\end{array}$ & $\begin{array}{l}\text { Building brand commitment: A } \\
\text { behavioral approach to internal brand } \\
\text { management }\end{array}$ & $\begin{array}{l}\text { Brand Commitment } \rightarrow \text { Brand Citizenship Behavior } \\
\text { Brand Citizenship Behavior } \rightarrow \text { The Quality of Relationship between } \\
\text { Customer and Brand } \\
\text { Internal Communications of Brand } \rightarrow \text { Brand Commitment } \\
\text { Brand-Based Human Resources Management } \rightarrow \text { Brand Commitment }\end{array}$ \\
\hline $\begin{array}{l}\text { Punjaisri\& Wilson } \\
\text { (2011) }\end{array}$ & $\begin{array}{l}\text { Internal branding process: Key } \\
\text { mechanisms, outcomes, and } \\
\text { moderating factors }\end{array}$ & $\begin{array}{l}\text { Brand Commitment } \rightarrow \text { Brand Loyalty } \\
\text { Involvement with Brand } \rightarrow \text { Brand Commitment } \\
\text { Commitment, Loyalty, and Involvement with Brand } \rightarrow \text { Brand Efficiency } \\
\text { Organization's Branding } \rightarrow \text { Commitment, Loyalty, and Involvement with } \\
\text { Brand }\end{array}$ \\
\hline King \& Grace (2009) & $\begin{array}{l}\text { Employee based brand equity: A third } \\
\text { perspective }\end{array}$ & $\begin{array}{l}\text { Brand Equity based on Employees, Brand Citizenship Behavior, } \\
\text { Employees' Satisfaction, Brand Loyalty, and Positive Word of Mouth } \\
\text { Feedback from Employees } \rightarrow \text { Internal Communications of Brand } \\
\text { Internal Communications of Brand } \rightarrow \text { Internal Brand Equity }\end{array}$ \\
\hline
\end{tabular}




\section{The Study}

In this section, the preliminaries of the current research are given. In this regard, the conceptual model, hypotheses, and related methodology are introduced.

\section{The Conceptual Model}

The conceptual model for investigating the effective factors on human resource branding and reputation is established by means of the previous studies. Figure 2 illustrates such a model consisting of 5 variables including planning, training, employment, services compensation, and performance appraisal. These variables are related to human resource management process. Three variables, called satisfactory, commitment, and competence (loyalty) beside of the reputations also exist in the model.



Figure 2.The conceptual model of the research

\section{Research Hypotheses}

According to the model of the research and related works, the hypotheses are extracted to be tested in this subsection. In this regard, the most related works in the literature can be referred as Mosely (2007) and also Foster (2010). Generally speaking, the mentioned hypotheses aim at testing the relations and impact of human resource branding in different parts of the organization. The mentioned hypotheses are as follows:

$\mathbf{H}_{1}$ : Human resources processes have a positive effect on employees' competency.

$\mathbf{H}_{2}$ : Human resources processes have a positive effect on employees' commitment (loyalty).

$\mathbf{H}_{3}$ : Human resources processes have a positive effect on employees' satisfaction.

$\mathbf{H}_{4}$ : Employees' competency in Social Security Organization has a positive effect on their commitment (loyalty) to the brand of the organization.

$\mathbf{H}_{5}$ : Employees' commitment (loyalty) in Social Security Organization has a positive effect on their satisfaction of the brand of the organization. 
$\mathbf{H}_{6}$ : Employees' competency in Social Security Organization has a positive effect on the reputation and brand of the organization.

$\mathbf{H}_{7}$ : Employees' commitment (loyalty) in Social Security Organization has a positive effect on the reputation and brand of the organization.

$\mathbf{H}_{8}$ : Employees' satisfaction in Social Security Organization has a positive effect on the reputation and brand of the organization.

\section{Method}

The present study is an applied research in terms of goal adopting a descriptive method in terms of data collection. Following this, the current study is applicable since its results can be useful in managing the brand of service organizations and adopting strategies to improve it. According to the conceptual model, the research is descriptive and correlational.

In order to study the processes of human resources, the model of human resources management in IDRO was applied: This model was selected since it is an internal model and it is confirmed by 150 managers of human resources which is used in most service organizations.

To determine the staffs ' criterion and measure in human resource branding, competence and job satisfactory is used which are approved by Harvard business school and (Kaplan \& Norton, 2001) theory, respectively (Stoner, Freeman, \& Gilbert Jr., 2009). The measures and criterion are confirmed by 10 experts in research industry

To investigate the factors effective in internal human resources branding, the statistical population of this research included all employees of Social Security Insurance in different branches of Alborz Province (270 individuals). Since the population list was available, cluster sampling was applied and in order to determine the number of samples to distribute the questionnaire, Morgan table determined number of samples equal to 159; where 240 questionnaires are distributed which 162 of them are filled and finally 159 ones are selected for statistical analysis. The data was collected according to five-point Likert Scale and through directly referring to employees and self-report.

To measure the validity of questions, factor validity was applied which is a sort of structure validity that is achieved through confirmatory factor analysis. In order to make sure of the content validity of the questionnaire, the questionnaire was adjusted by related professors and a number of experts in Social Security Organization. Cronbach's Alpha for latent variables in Table 2 confirms the reliability of the questionnaire. Table 2 shows the confirmatory factor analysis.

Table 2

Standard Factor Loadings and Cronbach's Alpha

\begin{tabular}{cccc}
\hline Number & Latent Variable & Alpha & Total Questionnaire \\
\hline 1 & Human Resources & 0.80 & \\
2 & Employees' Competency & 0.78 & 0.79 \\
3 & Employees' Commitment and Loyalty & 0.77 & \\
4 & Employees' Satisfaction & 0.81 & \\
5 & Brand Reputation & 0.83 & \\
\hline
\end{tabular}

In the current study, to analyze the data, the two-phase method has been conducted. In thefirst phase, confirmatory factor analysis is performed and in the second phase, path analysis 
isused to analyze the relationships between the structures. Therefore, for data analysis andmodel confirmation, structural equation model (SEM) and confirmatory factor analysis(CFA) are performed and according to the results of path analysis, the relationships betweenmodel variables are investigated. AMOS software has been used to test the hypothesis andfitness of the model. Table 3 presents the researchers' criteria in measuring variables ofresearch.

Table 3

Researchers' Criteria in Measuring Variables of Research

\begin{tabular}{ll}
\hline Variables & Researchers \\
\hline Process of H.R.M in IDRO Model & Mohammadi\&Varzeshkar (2010) \\
& Industrial Development and Renovation Organization of Iran \\
Competency & Stoner et al. (2009) \\
Commitment (Loyalty) & Stoner et al. (2009) \\
Satisfactory & Kaplan \& Norton (2001) \\
\hline
\end{tabular}

\section{Results}

\section{Demographic Findings}

Demographic characteristics of the studied sample are summarized in under.Fifty-two percent of employees are between 31 and 40 years old that include the highest percentage of the sample. The lowest share is devoted to the age range of 18 to 30 years old. Following this, $94 \%$ of respondents are men and 6\% are women. The highest frequency in terms of education is devoted to BA (58\%) and the lowest frequency is devoted to Ph.D. (11\%). In terms of work experience, the highest frequency is related to the age range of 31 to 40 years old $(52 \%)$ and the lowest one is related to 18 to 30 years $(12 \%)$.

The aim of theresearch is to investigate the relationship between the variables of the research and create the causal model, model test, and modeling. Therefore, there are two main issues in the research. First, measuring the related variables, i.e. what is the research tool going to measure and how accurate is its measurement? Second, the comprehensive and latent causal relationships between the variables, which are not directly observable, are realized and the extent of latent relationships between these variables are evaluated through observable variables that are undoubtedly fallible. Therefore, studying the correlation and analyzing the regression through structural modeling are the best ways to test the model and hypotheses. In order to accomplish the aim of the research, first the measuring model of relationships between observed variables and latent variables was determined, then the correlational and causal relationships between latent variables and causal effects and the amount of explained and unexplained variance were identified. The theoretical model and hypotheses of the research are investigated through the structural modeling. In this investigation, three steps of evaluating the process of the whole model, evaluating the measuring section of the model, and evaluating the structural section of the model have been taken. The aim of evaluating the process of the whole model is to determine that to what extent the whole model is compatible with the empirical data. In evaluating the measuring section of the model, the relationships between latent and observed variables and markers are studied. The conceptual model of the research was studied through the method of maximum likelihood and the parameters of the model were estimated by the observed data. The results have indicated that the general model is significant. In order to judge the general model, the indices of root mean square error, unmeasured proportion, and 
comparative proportion can be applied. The results of evaluating the process of the whole model indicate that the theoretical model is compatible with the empirical data. Moreover, the observed markers are significantly related to the latent variables.

\section{The Model and its Analysis.}

In this paper, the model of measuring (An investigation of the factors effective in human resources branding and its effect on the reputation and brand of theinsurance industry) is a structural equation model and includes the whole relationships between its variables. In fact, a structural equation model is a combination of path diagram and confirmatory factor analysis and to investigate them, the method of structural equation model is conducted. The final model derived from data collection is illustrated in Figure 3.

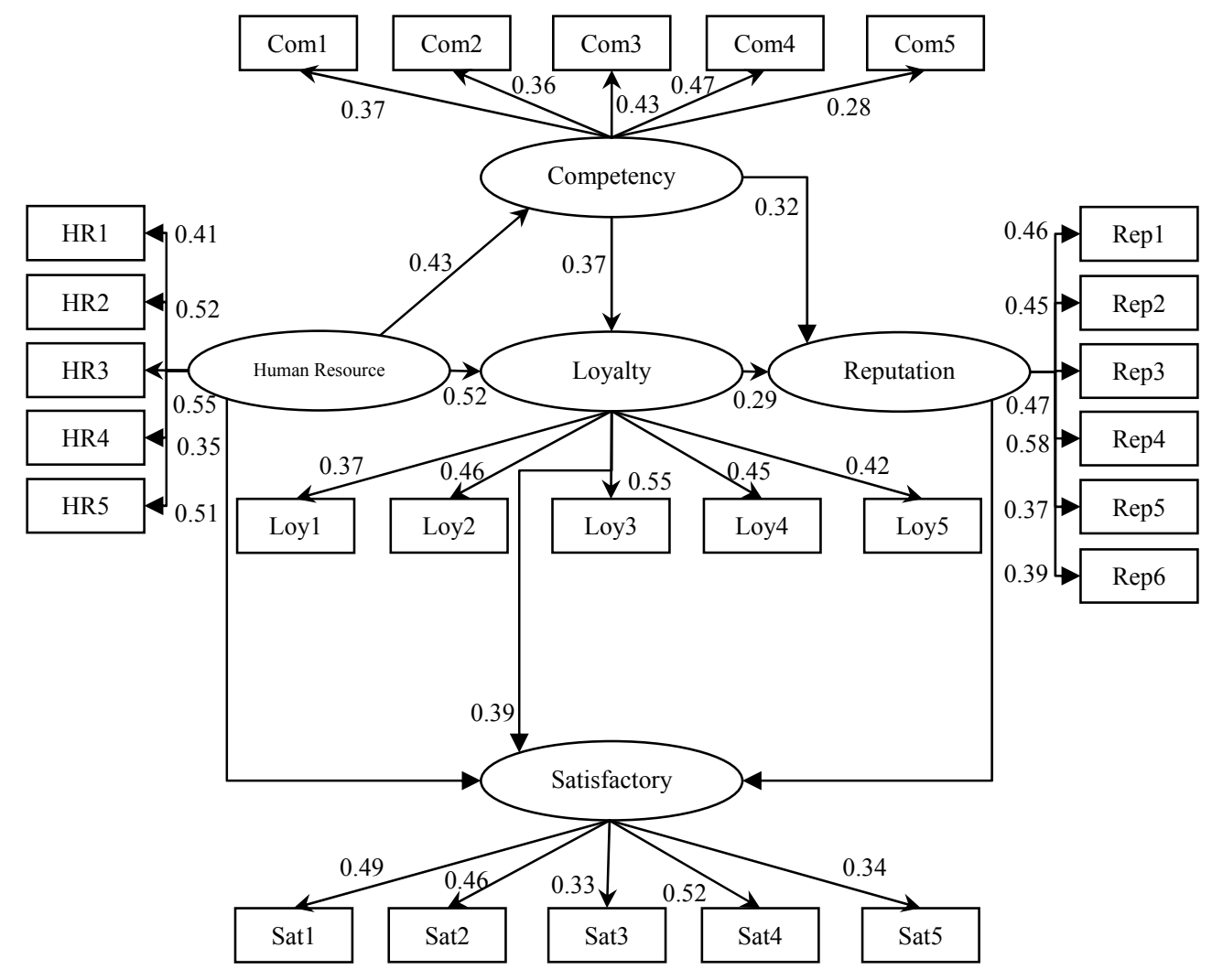

Figure 3. Operating model of the research

In confirmatory factor analysis, there are many criteria for evaluating thefitness of the model.

In Table 4, the accepted fitness and earned values are presented for the research model through AMOS software.

Table 4

Earned Values in AMOS

\begin{tabular}{llll} 
CMIN/DF & 2.08 & RMR & 0.21 \\
$\mathrm{P}$ & 0.00 & CFI & 0.93 \\
GFI & 0.94 & RMSEA & 0.03 \\
\hline
\end{tabular}


The Chi-Square statistic is an absolute index. The smaller the Chi-Square value (CMIN) is, the better the pattern fit formulated by the researcher will be. If theP value is greater than 0.05 , Chi-Square value for the pattern will be acceptable; thus, it can be concluded that there is no significant difference between the observed variance and co-variance matrixes and the reproduced variance and co-variance matrixes. The $\mathrm{P}$ value for the mentioned pattern is appropriate and it is higher than 0.05 .

One of the general indices to include free parameters in calculating the fit index is the normed or relative Chi-Square, which is calculated from the simple division of Chi-Square by the model's degree of freedom. Values of 1 to 3 are usually considered acceptable for this index. However, there are different viewpoints. According to the calculated value, this value is acceptable.

The index of GFI is a comparative index and values greater than 0.90 indicate the good fit pattern. GFI for models higher than 0.90 indicates that there is no significant difference between the reproduced variance and co-variance matrixes and the observed variance and covariance matrixes (good fit patterns). The GFI value for the mentioned pattern is acceptable.

The residual matrix is one of the important matrixes that can be used for evaluating both the general fit (the formulated pattern) and the partial fit (the defined parameter between two variables). Root mean square residual (RMR) for the mentioned pattern is a small value, thus the fit is acceptable.

Comparative fit index (CFI) is one of the comparative indices that values between 0.90 and 0.95 are considered acceptable. Moreover, values higher than 0.90 for this index are interpreted as agood fit. The value of CFI for the mentioned pattern is acceptable.

Root Mean Square Error of Approximation (RMSEA) is based on the residual matrix analysis same as RMR. Acceptable patterns are equal to or smaller than 0.08 for this index. The fitness of patterns that is higher than 0.1 is considered weak. According to Table 6 , the value of this index for the mentioned pattern indicates that this index has a weak fit pattern. In fact, it can be concluded that the general indices indicate the good fit pattern by data and the collected data supports the pattern properly.

These indexes indicated the fitness of designed model. In fact, the theoretical model of the research is confirmed. Since this model was confirmed by fit indexes, we can use it to test thehypotheses. If the model which is drawn as a diagram is confirmed by thefitness of model indices, this path diagram can be used to test hypotheses to know whether there are relationships between variables of path diagram or not. Path diagram includes relationshipsbetween the variables of the research which indicates the general model of the study and its hypotheses. In addition to the general fit indexes of the model, the partial fit indexes are investigated in the structural equation model as well. In partial fit indexes, the significance of all the relationships in the model is tested. 
In order to test the significance of hypotheses, two indices of critical value and $\mathrm{P}$ value were used. The critical value is calculated from the division of "weighted regression estimation" by "standard error". According to the significance level of 0.05 , thecritical value must be higher than 1.96, since lower values are not considered important. Moreover, lower values than 0.05 for $\mathrm{P}$ value indicate the significant difference of calculated value for weighted regression $(0)$ at aconfidence level of 0.95 . Standard regression coefficient, as well as critical values and $p$ values for eight hypotheses, are included in Table 5.

Table 5

Research Variables Path

\begin{tabular}{|c|c|c|c|c|c|}
\hline Hypothesis & Path & Path Coefficient & Critical Value & Significance & Results \\
\hline 1 & Human Resources $\rightarrow$ Competency & 0.73 & 4.67 & $* * *$ & Confirmed \\
\hline 2 & Human Resources $\rightarrow$ Commitment & 0.66 & 5.22 & $* * *$ & Confirmed \\
\hline 3 & Human Resource $s \rightarrow$ Satisfactory & 0.88 & 5.85 & $* * *$ & Confirmed \\
\hline 4 & Competency $\rightarrow$ Commitment & 0.61 & 4.22 & $* * *$ & Confirmed \\
\hline 5 & Commitment $\rightarrow$ Satisfactory & 0.54 & 3.25 & $* * *$ & Confirmed \\
\hline 6 & Competency $\rightarrow$ Reputation & 0.67 & 4.36 & $* * *$ & Confirmed \\
\hline 7 & Commitment $\rightarrow$ Reputation & 0.57 & 5.42 & $* * *$ & Confirmed \\
\hline 8 & Satisfactory $\rightarrow$ Reputation & 0.65 & 5.74 & $* * *$ & Confirmed \\
\hline
\end{tabular}

According to $\mathrm{H}_{1}$, human resources processes had a positive effect on employees' competencies. The regression coefficient for this hypothesis was equal to 0.73 , which confirmed the hypothesis. Moreover, $\mathrm{P}$ value for this hypothesis was lower than 0.00 , which again confirmed the hypothesis. Therefore, at aconfidence level of 0.99 , it was concluded that human resources processes had a positive effect on employees' competencies.

Considering $\mathrm{H}_{2}$, human resources processes had a positive effect on employees' commitment (loyalty). The regression coefficient for this hypothesis was equal to 0.66 , which confirmed the hypothesis. Moreover, $\mathrm{P}$ value for this hypothesis was lower than 0.00 , which again confirmed the hypothesis. Therefore, at aconfidence level of 0.99 , it was concluded that human resources processes had a positive effect on employees' commitment (loyalty).

Regarding $\mathrm{H}_{3}$, human resources processes had a positive effect on employees' satisfaction. The regression coefficient for this hypothesis was equal to 0.88 , which confirms the hypothesis. Moreover, P value for this hypothesis is lower than 0.001 , which again confirmed the hypothesis. Therefore, at aconfidence level of 0.99 , it was concluded that human resources processes had a positive effect on employees' satisfaction.

According to $\mathrm{H}_{4}$, employees' competency in Social Security Organization had a positive effect on their commitment (loyalty) to the brand of the organization. The regression coefficient for this hypothesis was equal to 0.61 , which confirmed the hypothesis. Moreover, $\mathrm{P}$ value for this hypothesis was lower than 0.00, which again confirmed the hypothesis. Therefore, at aconfidence level of 0.99, it was concluded that employees' competency in Social Security Organization had a positive effect on their commitment (loyalty) to the brand of the organization.

Regarding $_{5}$, employees' commitment (loyalty) in Social Security Organization had a positive effect on their satisfaction of the brand of the organization. The regression coefficient for this hypothesis was equal to 0.54 , which confirms the hypothesis. Moreover, $\mathrm{P}$ value for 
this hypothesis was lower than 0.00 , which again confirmed the hypothesis. Therefore, at aconfidence level of 0.99, it was concluded that employees' commitment (loyalty) in Social Security Organization had a positive effect on their satisfaction at the brand of the organization.

ConsideringH $_{6}$, employees' competency in Social Security Organization had a positive effect on the reputation and brand of the organization. The regression coefficient for this hypothesis was equal to 0.67 which confirmed the hypothesis. Moreover, $\mathrm{P}$ value for this hypothesis was lower than 0.00 that again confirmed the hypothesis. Therefore, at aconfidence level of 0.99, it was concluded that employees' competency in Social Security Organization had a positive effect on the reputation and brand of the organization.

According to $\mathrm{H}_{7}$, employees' commitment (loyalty) in Social Security Organization had a positive effect on the reputation and brand of the organization. The regression coefficient for this hypothesis was equal to 0.57 which confirms the hypothesis. Moreover, $\mathrm{P}$ value for this hypothesis was lower than 0.00 that again confirmed the hypothesis. Therefore, at aconfidence level of 0.99, it was concluded that employees' commitment (loyalty) in Social Security Organization had a positive effect on the reputation and brand of the organization.

Regarding $_{8}$, employees' satisfaction in Social Security Organization had a positive effect on the reputation and brand of the organization. The regression coefficient for this hypothesis was equal to 0.6568 , which confirmed the hypothesis. Moreover, $\mathrm{P}$ value for this hypothesis was lower than 0.001 which again confirmed the hypothesis. Therefore, at aconfidence level of 0.99, it was concluded that employees' satisfaction in Social Security Organization had a positive effect on the reputation and brand of the organization.

\section{Discussion and Conclusion}

There are some limitations to this research. The findings of this study are limited to the time and place dimensions. In fact, this research is conducted in the insurance industry in a particular period of time and its respondents are different from the respondents of other universities in terms of knowledge, experience, and activity. Moreover, the aim of this research is to investigate factors effective in human resources branding and its effect on the reputation and brand of theinsurance industry, while it can be conducted in other companies and public and private organizations and different results may be achieved. Another limitation refers to the few number of experts and those who are familiar with the dimensions and characteristics of the conceptual model to score the questions. In addition, some respondents resisted answering the questions and avoided cooperating with the researcher, thus the small number of samples may affect the results. The last limitation to this research is due to the human science researches, since the results of this field are not definite, especially the political and economic conditions of the country that are out of control and may affect the respondents and the results of the research. Therefore, it is recommended that the results of the research be applied carefully.

Regarding the results of the main hypothesis of the research, it is recommended that job and organizational knowledge be increased through training courses. Moreover, self-control culture in the organization must be created, so that all employees will be responsible for their mistakes and will find the solution. Ethical and work charters must be formulated according to the mission, objectives, and perspective of the organization for different sections of the organization. The charters of the company must ensure the employee that the activities and 
objectives of the company are in line with the work and financial mentality of employees. Furthermore, the culture of lawfulness and respecting organizational values must be highly emphasized. Following this, evaluation systems should be formulated, trust in work relationships and transparency in working should be increased, and work conditions should be improved. People who try to be promoted or deserve further rewards and employees who need further training must be identified. Moreover, jobs and organizational positions must be reconsidered and employees' relationship with the strategies and objectives of the organization must be clarified. Finally, performance indices must be determined.

For future researches, there are some more recommendations. For example, this research can be undertaken in other private and public organizations. Moreover, other components and dimensions can be identified according to the conceptual model of this research. This research can also be conducted at other times and the results can be compared to study the effect of time component on the results. In addition, different moderator variables in the model can be studied. Finally, qualitative studies can be conducted and a comprehensive scale to measure the internal branding can be designed.

\section{References}

Ahmad, N. A., \& Daud, S. (2016). Engaging people with employer branding. Procedia Economics \& Finance, 35, 690-698.

Alipour, H., \& Farid, M. (2013). An investigation of job satisfaction in employees of Keshavarzi Bank of Lahijan. Quantitative Studies in Management, 4(2), 115-126.

Bagheri, M., \& Tavalaee, R. (2010). An investigation of the effect of organizational commitment on the performance of organizations. Police Human Development, 30, 73-96.

Baumgarth, C., \& Schmidt, M. (2010). How strong is the business-to-business brand in the workforce? An empirically-tested model of internal brand equity in a business-to-business setting. Industrial Marketing Management, 39(8), 1250-1260.

Burmann, C., \& Zeplin, S. (2005). Building brand commitment: A behavioral approach to internal brand management. Journal of Brand Management, 12(4), 279-300.

Eivazzadeh, E., \& Moinan, D. (2011). The effect of human resources management on improving the efficiency of staff in Islamic Azad University, East of Tehran Branch. Research in Curriculum Planning, 1(27), 297-306.

Foster, C., Punjaisri, K., \& Cheng, R. (2010). Exploring the relationship between corporate, internal and employer branding. Journal of Product \& Brand Management, 19(6), 401-409.

Ghorbanifard, B., Hashemnia, S., \&Mousavi, S. S. (2014). The effect of organizational atmosphere dimensions on thebrand promise (Case study: Maskan Bank). Marketing Management, 9(22), 117-130.

Gull, S., \& Mubeen Ashraf, S. (2012). The impact of internal branding on service employee's quality commitment - study on education sector of Pakistan. International Journal of Business \& Social Science, 3(14), 302-311.

Hosseini, S. Y., Mousavi, S. A., \& ZiaeeBideh, A. (2013). Presenting a model for employee-based brand equity in business insurance office of Yazd Province. Journal of New Marketing Research, 3(1), 1-16.

Johansson, J. (2008). Working with events to build a destination brand identity-The DMO perspective (Unpublished master's thesis). University of Gothenburg, Sweden.

Kafashpour, A., \& Niakan, S. R. (2011). Recognizing the effective and determining inter-organizational factors to create a valuable brand. Business Management Searches, 3(5), 97-117.

Kaplan, R.S.,\& Norton, D.P. (2001). The strategy-focused organization. Strategy and Leadership, 29(3), 41-42.

Kimpakorn, N., \& Tocquer, G. (2010). Service brand equity and employee brand commitment. Journal of Services Marketing, 24(5), 378-388.

King, C., \& Grace, D. (2009). Employee based brand equity: A third perspective. Services Marketing Quarterly, 30(2), 122147.

Kotler, P. (2003). Marketing management (11 ${ }^{\text {th }}$ ed.). US: Pearson Education.

Mohammadi, A., \& Varzeshkar, A. (2009). Introducing the pattern of researches human resources management in a military organization. Human Resources Management Researches, 1(1), 51-78. 
Mohammadi Zanjirani, D., Eshtiaghian, N., \& Raznahan, F. (2012). A multi-criteria and integrated approach of educational need-assessment based on analysis of employees' competencies. Journal of New Educational Approaches, 7(1), 107-136.

Mosley, R. W. (2007). Customer experience, organizationalculture, and the employer brand. Journal of Brand Management, 15(2), 123-134.

Omidikia, K., Moshabbaki, A., Khodadadhosseyni. S., H. Azizi, SH. (2012). Identifying organizational capabilities to establish brand equity in food industry using data based theorem, Strategic Management Thinking, 6(9),35-75

Punjaisri, K., \& Wilson, A. (2011). Internal branding process: Key mechanisms, outcomes, and moderating factors. European Journal of Marketing, 45(9/10), 1521-1537.

Punjaisri, K.,Wilson, A.,\& Evanschitzky,H.(2014).Exploring the influences of internalbranding on employees' brand promise delivery: Implications for strengthening customer-brand relationships. Journal ofRelationship Marketing,7(4),407-424

Sanavifard, R. (2014). Designing employees' brand model based on individual and organizational values in increasing market share (Case study: Mellat Bank) (Unpublished doctoral dissertation). Payame Noor University, Central Organization, Faculty of Management, Iran.

Schlager, T., Bodderas, M., Maas, P., \& Cachelin, J. L. (2011).The influence of the employer brand on employee attitudes relevant for service branding: An empirical investigation. Journal of Services Marketing, 25(7), 497-508.

Seddighi, A. (2015). An investigation of the effect of internal branding on services quality commitment of employees in banks (Case study: Mellat Bank) (Unpublished master's thesis). Islamic Azad University Central Tehran Branch, Iran.

Shafizadeh, H., \& Kamrava, H. (2014). The study of therelationship between job satisfaction and life satisfaction in employees of Semnan Medical Science University. Cultural Management, 8(2), 79-89.

Sheida, M., Hemmati, M., \& Fakhari, M. (2014). Analyzing the role of human resources in brand success and presenting a conceptual model. The 2nd National Conference on Applied Researches in Management and Accounting. Tehran, Iran: University of Applied Science and Technology.

Spencer, R. J., \& Byrne, M. K. (2016). The relationship between the extent of psychopathic features among corporate managers and subsequent employee job satisfaction. Personality and Individual Differences, 101, 440-445.

Stoner, J. A., Freeman, R. E., \& Gilbert Jr, D. R. (2009). Management $\left(6^{\text {th }}\right.$ ed.). Pearson Publication.

Wallace, E., de Chernatony, L., \& Buil, I. (2013). Building bank brands: How leadership behavior influences employee commitment. Journal of Business Research, 66(2), 165-171.

Whiteoak, J. W., \& Mohamed, S. (2016). Employee engagement, boredom, and frontline construction workers feeling safe in their workplace. Accident Analysis \& Prevention, 93, 291-298.

Zaman Fashami, R. (2013). An investigation into the key factors of internal branding success in Saderat Bank of Tehran City (Unpublished master's thesis). Payame Noor University, Iran. 